\title{
PRODUCTIVE AND REPRODUCTIVE PERFORMANCE OF DIFFERENT CROSSBRED CATTLE AT SYLHET GOVT. DAIRY FARM
}

\author{
M. N. Haque, M. R. Haque ${ }^{1}$, A. Parvin ${ }^{2}$ and M. M. Hussain ${ }^{3}$ \\ Dept. of Genetics \& Animal Breeding, Sylhet Agricultural University, Sylhet, Bangladesh
}

\begin{abstract}
The study was conducted at Sylhet Govt. dairy farm to evaluate the productive and reproductive performance of Jersey $\times$ Frisian $(\mathrm{J} \times \mathrm{F})$, Jersey $\times$ Local $(\mathrm{J} \times \mathrm{L})$ and Sahiwal $\times$ Local $(\mathrm{SL} \times \mathrm{L}$.) crossbred during the period of April 2007 to August 2009. Data on milk yield and different reproductive traits like lactation length, milk yield, length of dry period, service per conception, gestation length and post-partum heat period were evaluated. Results indicated that milk yield, length of dry period, service per conception and post-partum heat period were significantly affected $(\mathrm{P}<0.01)$ by different crossbred. However, lactation length and service per conception were significantly affected $(\mathrm{P}<0.01)$ by parity and interaction of breed $\times$ parity. The highest lactation length was observed for the genotype Jersey $\times$ Friesian $(\mathrm{J} \times \mathrm{F})$ and the lowest was Jersey $\times$ Local $(\mathrm{J} \times \mathrm{L})$ in the first and second lactation. The highest milk yield was observed for the genotype $\mathrm{J} \times \mathrm{F}$ and the lowest was $\mathrm{J} \times \mathrm{L}$. The highest length of dry period was observed in $\mathrm{SL} \times \mathrm{L}$ and lowest was J $\times \mathrm{F}$. Furthermore maximum services were required for $\mathrm{J} \times \mathrm{F}$. The highest gestation length was observed for genotype $\mathrm{SL} \times \mathrm{L}$. The highest post-partum heat period was observed $\mathrm{J} \times \mathrm{F}$. The overall reproductive performance of different crossbreds were varied.
\end{abstract}

Key Words: Crossbreds, Reproductive traits, Milk yield

\section{INTRODUCTION}

Reproductive efficiency of cow is inseparably associated with the profitability in dairy industry. The landless and marginal farmers largely depend on livestock for their survival any reared indigenous cattle (Ahmed, 1992). Crossbred cattle reared by the large farmer are facing several types of difficulties due to lack of managemental knowledge. Cattle of Bangladesh is an inseparable and integrated part of the agricultural operation and it ranks twelfth in cattle population in the world and in the Asian countries its position is third but it yields only $21 \%$ of the world's milk production and $34 \%$ of the beef production (Alam et al., 2007; Rahman, 2009).

The latest estimate of livestock is about 23.03 million head of cattle, 1.35 million buffalo, 2.97 million sheep, 23.27 million goats, 228.04 million chicken and 42.68 million duck (BBS, 2010). Despite this large cattle population in the country, the output of milk falls short of

1 Dept. of Animal Science and 2Section Officer Grade-1, SAU, Sylhet, ${ }^{2}$ Lecturer, Dept. of Agricultural studies, Imam Gazzali Girls School \& College, Pabna, Bangladesh 
requirement. The average milk of indigenous dairy cows are only 137 liters per lactation (DLS, 2006). This low productivity of the native cows is mainly due to poor genetic potentials. But on the other hand, it is important to note that prevailing environmental condition is not suitable for raising high productive exotic breeds. It is estimated that daily per capita requirement of milk is $250 \mathrm{ml}$ and thus annual requirement stands at about 9.86 million metric tones for the country (DLS, 2006). It is alarming that the present daily per capita availability of milk is only $33.95 \mathrm{ml}$ and total annual production is estimated to be 1.34 million metric tones. Hence, annual deficit of milk in the country is about 8.52 million metric tones. In Bangladesh about 87 per cent of its population are undernourished and the country has been suffering from an acute shortage of milk and milk products. To meet the deficit, the country has to import milk and milk products from abroad every year spending huge amount of foreign currency which is about Tk. 2901 million (BBS, 2010). Not only, that milk and milk products of some countries may still contain radioactive substances, which have hazardous impact on public health especially for children.

Livestock development depends mainly on genetic potential of the animal. Optimum nutrition, disease control and managemental practices permit full expression of this genetic potential. Climatic stress in the form of high ambient temperature, high humidity and erratic or inadequate rainfall affects the productivity of dairy cattle in the tropics (Ansell, 1985).

It is an important factor to maintain right genotype in the right environment for the expression of full genetic potentiality. Any deviation in the genetic environment interaction will cause serious consequence on productivity. Reproductive pattern and ability are directly involved in overall productivity of animals. The reproductive adaptability in the given environment must be considered as one of the major tasks for any improvement attribute. It is reported from other parts of the developing countries as well as the experience gathered already from home country, that productive performance of crossbred cows is not promising to a certain extent. This might be due to lack of adaptability in unfavourable environmental conditions, lack of availability and cost maintenance for such type of high yielding variety in the existing socio-economic condition. Whatever the avenue of genetic improvement is used, the identification of best genotype within and among the breeding stock is the most important.

Considering the above facts and circumstances, the present study was undertaken with the objectives to study the milk production and reproductive potentials of different crossbred cows under farm conditions, as well as to recommend a suitable genotype.

\section{MATERIALS AND METHODS}

The study was conducted at Sylhet Govt dairy farm. The data were collected from the farm records during the period of 2004-2007. The information on the productive and reproductive performances of 108 cows of different genotypes was collected for this experiment. The experimental animals were divided into three genetic groups according 
to their genetic composition, such as Jersey $\times$ Local $(\mathrm{J} \times \mathrm{L})$, Jersey $\times$ Friesian $(\mathrm{J} \times \mathrm{F})$, and Sahiwal $\times$ Local $(S L \times L)$. Feeding and management system in the dairy farm were almost uniform throughout the year. Stall feeding and grazing was practiced through out the year. Concentrate feeds were given two times a day, at morning before milking and at afternoon. Concentrate feeds include wheat bran, till oil cake, rice bran, kheshari and common salt. Green grasses were supplied in the afternoon. Different types of green grasses such as German, Para, Napier etc. were cultivated in field farm area. Six traits mostly relating to production and reproduction were considered in this analysis such as: lactation length, milk yield, length of dry period, service per conception, gestation length and post-partum heat period. The number of observations varied from class to class. So, the statistical design of the study was non orthogonal factorial in nature, (Snedecor and Cochran, 1980). The Least-Squares procedure was used to analyze the fixed main effects such as gestation length, number of service per conception, lactation length, length of dry period, post-partum heat period and milk yield. For all traits linear fixed model (model 1) was used. For the Least-Squares analysis the computer program Harvey (1990) was used. The best fitting model for the analyzed trait is given below:

$$
Y_{i j k}=\mu+G_{j}+L_{1}+\left(G^{*} L\right)_{i j}+e_{i j k}
$$

Where,

$\mathrm{Y}_{\mathrm{ijk}}=\mathrm{Kth}$ record on a trait of cow in the ith genetic group and jth lactation number.

$\mu=$ The overall population mean

$\mathrm{G}_{\mathrm{j}}=$ Effect of ith genetic group (1-5)

$\mathrm{L}_{\mathrm{j}}=$ Effect of $\mathrm{jth}$ lactation number (1-2)

$\left(\mathrm{G}^{*} \mathrm{~L}\right)_{\mathrm{ij}}=$ Genotype $\times$ Lactation interaction effects

$\mathrm{e}_{\mathrm{ijk}}=$ Random error associated with individual observation.

For mean comparisons LSD was calculated by computer using MSTAT programme.

\section{RESULTS AND DISCUSSION}

\section{Lactation length}

The Least-Square means of lactation length along with standard error for different genetic groups are presented in Table 1 . The highest lactation length was observed in J×F $(340.60 \pm$ 33.40 days for first lactation and $285.40 \pm 50.20$ days for second lactation). The lowest lactation length was found in SL $\times \mathrm{L}(270.00 \pm 16.71$ days $)$ for first lactation and in $\mathrm{SL} \times \mathrm{L}$ (144.00 \pm 38.85 days) for second lactation. The Least-Squares analysis of variance showed that lactation length was significantly affected by parity $(\mathrm{P}<0.01)$ and genotype $\mathrm{x}$ parity interaction $(\mathrm{P}<0.01)$. LSD test indicates there was significant difference between the genotypes $\mathrm{J} \times \mathrm{F}, \mathrm{J} \times \mathrm{L}$ and $\mathrm{SL} \times \mathrm{L}$ (Table 1 ). The analysis of variance for lactation length data indicated that $\mathrm{R}^{2}$ of the model was $27.9 \%$. It means that of the total variation available in the lactation length data. The results of this study agree with the findings of Sultana (1995), who also observed almost similar lactation length for different genotypes. 
Table 1. Least-Squares means with standard error for productive and reproductive traits of different genetic groups of cows in first parity

\begin{tabular}{l|c|c|c|c|c}
\hline \multirow{2}{*}{$\begin{array}{c}\text { Genetic } \\
\text { group }\end{array}$} & \multicolumn{5}{c}{ Trait } \\
\cline { 2 - 6 } & $\begin{array}{c}\text { Lactation } \\
\text { length (days) }\end{array}$ & $\begin{array}{c}\text { Length of dry } \\
\text { period (days) }\end{array}$ & $\begin{array}{c}\text { Service per } \\
\text { conception (NO) }\end{array}$ & $\begin{array}{c}\text { Gestation length } \\
\text { days (days) }\end{array}$ & $\begin{array}{c}\text { Post-partum heat } \\
\text { period (days) }\end{array}$ \\
\hline Overall & $291.49 \pm$ & $103.18 \pm$ & $1.04 \pm$ & $275.80 \pm$ & $99.60 \pm$ \\
Jersey $\times$ & 29.30 & $14.83(55)$ & $0.57(72)$ & $13.12(72)$ & $13.50(55)$ \\
Friesian & $300.94 \pm$ & $103.00 \pm$ & $1.09 \mathrm{ab} \pm$ & $261.06 \pm$ & $95.59 \pm$ \\
Shahiwal $\times$ & $27.00^{\mathrm{cd}} \pm$ & $80.00^{\mathrm{c}} \pm$ & $1.00 \pm$ & $6.87(32)$ & $7.006(27)$ \\
Local & $38.85(32)$ & $19.54(4)$ & $0.156(5)$ & $17.39(5)$ & $120.75^{\mathrm{a}} \pm$ \\
Jersey $\times$ & $340.60^{\mathrm{a}} \pm$ & $87.00^{\mathrm{c}} \pm$ & $1.00^{\mathrm{b}} \pm$ & $277.50 \pm$ & $18.21(4)$ \\
Friesian & $33.40(5)$ & $19.54(4)$ & $0.17(4)$ & $19.44(4)$ & $18.21(4)$ \\
Sahiwal $\times$ & $270.0^{\mathrm{bc}} \pm$ & $114.00 \pm$ & $1.00 \pm$ & $280.63 \pm$ & $85.00^{\mathrm{bc}} \pm$ \\
local & $16.71(4)$ & $17.476(5)$ & 0.126181 & $13.75(8)$ & $14.87(6)$ \\
\hline
\end{tabular}

Means with different superscript within the same column differ significantly, $(\mathrm{P}<0.05)$ or $(\mathrm{P}<0.0)$. Number in the parentheses indicate replication within each treatment

Chaudhury et al. (1994) analyzed full lactation length in four different types of Sahiwal $\times$ Holstein Friesian (Fi, Fz, Fs and F4) along with pure Sahiwal cross and they found the largest value in F4 (383.8 days) and the shortest in pure Sahiwal (262 days). Nahar et al. (1989) observed that the genetic group had a significant effect $(\mathrm{P}<0.01)$ on lactation length and they found the average value for Sahiwal $\times$ Local (Fi) to be 295.54 days.

\section{Milk yield}

The Least-Squares means \pm SE for total milk yield are presented in Table 3 . The highest milk yield observed in J×F $(880.60 \pm 56.40 \mathrm{~kg})$ for first lactation and $\mathrm{J} \times \mathrm{F}(980.80 \pm 210.52 \mathrm{~kg})$ for second lactation. The lowest milk yield was observed in for first lactation and in $\mathrm{J} \times \mathrm{L}$ $(361.00 \pm 182.65 \mathrm{~kg})$ for second lactation. The Least-Squares analyses of variance showed that the genotype had a significant $(\mathrm{P}<0.01)$ effect on milk production. LSD test indicated that $\mathrm{J} \times \mathrm{F}$ and differ significantly from $\mathrm{J} \times \mathrm{L}$, and $\mathrm{SL} \times \mathrm{L}$ (Table 1). The results of this study agrees with the findings of Nahar et al. (1992), who observed similar results. Chaudhury et al. (1994) reported that lactation production of Sahiwal was significantly lowest as compared to other crossbred groups. Nahar et al. (1989) observed the highest lactation production in Holstein $\times$ Local $(1992.39 \pm 1957 \mathrm{~kg})$ lowest in Sindhi $\times$ Local $(997.97 \pm 19.10$ $\mathrm{kg})$. They reported that different genotypes had a significant $(\mathrm{P}<0.01)$ effect on lactation yield. Rahman et al. (1987) observed the highest lactation yield in Local $\times$ Friesian cows (1765.48 liter). Local $\times$ Sindhi cows gave the poorest milk yield (1108.6 liter \pm 96.62$)$ among crossbred groups. Hossain and Routledge 11982) reported that the lactation yield of $1 / 2$ Local - $1 / 2$ Jersey and Local cows were 1858.5 and $213.00 \mathrm{~kg}$ respectively. Total milk yield in all lactations were adjusted into 305 days of standard lactation period. The Least Squares means of adjusted milk yield along with standard error for different genetic groups are presented in Table 3. The highest adjusted milk yield is observed in J $\times F(859.10 \pm 42.38$ 
liter) for first lactation and 1196.08 \pm 69.21 liter for second lactation. LSD test indicated that no significant differences were observed among genotypes.

\section{Length of dry period}

The Least-Squares means of length of dry period along with standard error for different genetic groups are presented in Tables 1 and 2. The highest length of dry period is observed in $\mathrm{L}(131.93 \pm 10.09$ days for first lactation and $133.00 \pm 14.77$ days for second lactation). The lowest length of dry period is observed in $\mathrm{J} \times \mathrm{L}(80.00 \mathrm{t} \pm 19.54$ days) for first lactation and in $\mathrm{J} \times \mathrm{F}(74.50 \pm 127.63$ days) for second lactation. The Least-Squares analysis of variance showed that the dry period was significantly affected $(\mathrm{P}<0.01)$ by genotype. It indicates that no significant differences were observed between $\mathrm{J} \times \mathrm{F}$ and $\mathrm{SL} \times \mathrm{L}$; $\mathrm{J} \times \mathrm{L}$ (Table 2).

Table 2. Least-Squares means with standard error for productive and reproductive traits of different genetic groups of cows in second parity

\begin{tabular}{l|c|c|c|c|c}
\hline \multirow{2}{*}{$\begin{array}{c}\text { Genetic } \\
\text { group }\end{array}$} & \multicolumn{5}{|c}{ Trait } \\
\cline { 2 - 6 } & $\begin{array}{c}\text { Lactation } \\
\text { length (days) }\end{array}$ & $\begin{array}{c}\text { Length of dry } \\
\text { period (days) }\end{array}$ & $\begin{array}{c}\text { Service per } \\
\text { conception (NO) }\end{array}$ & $\begin{array}{c}\text { Gestation length } \\
\text { days (days) }\end{array}$ & $\begin{array}{c}\text { Post-partum heat } \\
\text { period (days) }\end{array}$ \\
\hline Overall & $214.62 \pm$ & $101.38 \pm$ & $1.52 \pm$ & $276.53 \pm$ & $114.24 \pm$ \\
& $36.22(39)$ & $18.07(28)$ & $0.14(39)$ & $16.22(39)$ & $16.39(31)$ \\
Jersey $\times$ & $161.67 \mathrm{c} \pm$ & $76.44 \pm$ & $1.17 \mathrm{c} \pm$ & $275.42 \pm$ & $106.30 \pm$ \\
Friesian & $25.08(12)$ & 13.026191 & $0.10(12)$ & $11.22(12)$ & $11.526(10)$ \\
Jersey $\times$ & $144.00^{c} \pm$ & $94.20 \pm$ & $1.60 \pm$ & $274.60 \pm$ & $114.60 \pm$ \\
Local & $38.85(5)$ & $17.476(5)$ & $0.156(5)$ & $17.39(5)$ & $16.296(5)$ \\
Jersey $\times$ & $285.40^{\mathrm{a}} \pm$ & $74.50 \pm$ & $2.00^{\mathrm{a}} \pm$ & $277.00 \pm$ & $161.50^{\mathrm{a}} \pm$ \\
Friesian & $50.20(2)$ & $27.636(2)$ & $0.23(2)$ & $27.49(2)$ & $25.75(2)$ \\
Sahiwal $\times$ & $195.35 \pm$ & $128.80^{\mathrm{a}} \pm$ & $1.00^{\mathrm{d}} \pm$ & $277.38 \pm$ & $113.60 \pm$ \\
local & $25.71(18)$ & $17.47(5)$ & $0.12(8)$ & $13.75(8)$ & $16.296(5)$ \\
\hline
\end{tabular}

Means with different superscript within the same column differ significantly, $(\mathrm{P}<0.05)$ or $(\mathrm{P}<0.0)$

Number in the parentheses indicate replication within each treatment.

Which means that of the total variation available in the length of dry period data, the included factor in the model contributed only $22.8 \%$ and the rest of the variation remained unexplained or in the error term. The results of this study are in agreement with the findings of Dalal et al. (1991) and Nahar et al. (1989). Maroof et al. (1987), reported that dry period was affected $(\mathrm{P}<0.01)$ by calving season and calving period. But breed, parity and farm had no significant effects on dry period. Hossain and Routledge (1982) observed that the dry period of Local cows was significantly higher than that of pure breed and their crosses. They found that the dry period of Local cows were $275 \pm 136$ days and Jersey crosses were $57 \pm 29$ days. In the present study it was observed that the length of dry period of Local cows were very long in comparison with other crossbred cows. This variation is mainly contributed by genetic constituent of animal and the environmental factor. 
Table 3. Least-Squares means with standard error for milk yield $(\mathrm{kg})$ in cows of different genetic groups in pooled lactation

\begin{tabular}{|c|c|c|c|c|}
\hline \multirow{3}{*}{$\begin{array}{l}\text { Genetic } \\
\text { group }\end{array}$} & \multicolumn{4}{|c|}{ Trait } \\
\hline & \multicolumn{2}{|c|}{ Total milk yield } & \multicolumn{2}{|c|}{ Adjusted milk yield } \\
\hline & $\begin{array}{l}\text { First lactation } \\
\mathrm{LSM} \pm \mathrm{SE}\end{array}$ & $\begin{array}{l}\text { Second lactation } \\
\qquad \mathrm{LSM} \pm \mathrm{SE}\end{array}$ & $\begin{array}{l}\text { First lactation } \\
\mathrm{LSM} \pm \mathrm{SE}\end{array}$ & $\begin{array}{l}\text { Second lactation } \\
\qquad \mathrm{LSM} \pm \mathrm{SE}\end{array}$ \\
\hline Overall & $712.11 \pm 91.00(72)$ & $634.77 \pm 108.18$ & $740.72 \pm 80.85(72)$ & $900.34 \pm 99.10(39)$ \\
\hline $\begin{array}{l}\text { Jersey } \times \\
\text { Friesian }\end{array}$ & $880.60^{a} \pm 56.40(32)$ & $732.33 \pm 54.816(12)$ & $859.10^{a} \pm 42.38(32)$ & $1196.08 \mathrm{a} \pm 69.21(12)$ \\
\hline $\begin{array}{l}\text { Jersey } x \\
\text { Local }\end{array}$ & $629.00^{b c} \pm 82.65(5)$ & $361.00^{d} \pm 82.65(5)$ & $684.40^{\mathrm{bc}} \pm 107.22(5)$ & $741.20^{\mathrm{bc}} \pm 107.22(5)$ \\
\hline $\begin{array}{l}\text { Jersey } x \\
\text { Friesian }\end{array}$ & $852.75^{a} \pm 149.49(4)$ & $980.80^{a} \pm 210.52(2)$ & $762.00 \pm 119.886(4)$ & $1114.00^{a} \pm 169.55(2)$ \\
\hline $\begin{array}{l}\text { Sahiwal } \times \\
\text { local }\end{array}$ & $697.00^{b} \pm 105.71(8)$ & $573.50^{c} \pm 105.71(8)$ & $7375^{b c} \pm 84.77(8)$ & $788.50 \pm 84.776(8)$ \\
\hline
\end{tabular}

Means with different superscript within the same column differ significantly, $(\mathrm{P}<0.05)$ or $(\mathrm{P}<0.0)$

\section{Service per conception}

The Least-Squares means of service per conception along with standard error for different genetic groups are presented in Table 1 and 2 . The lowest service per conception was observed in $\mathrm{J} \times \mathrm{L}(1.00 \pm 0.15), \mathrm{F} \times \mathrm{L}(1.00 \pm 0.17)$ and $\mathrm{SL} \times \mathrm{L}(1.00 \pm 0.12)$ for first lactation and in SL $\times \mathrm{L}(1.00 \pm 0.12)$ for second lactation. Analysis of variance showed that the number of services per conception was significantly $(\mathrm{P}<0.01)$ affected by genotype, parity and the interaction of genotype $\times$ parity. LSD test indicates no significant difference among the genotypes $\mathrm{J} \times \mathrm{F}, \mathrm{J} \times \mathrm{L}$ and $\mathrm{SL} \times \mathrm{L}$. The rest of the variation remain unexplained or in the error term. The results of these studies are in agreement with those found by Chaudhury et al. (1994), who observed almost similar services per conception for different genotypes. Sultana (1995) studied on the performance of exotic cattle breeds and their crosses in Bangladesh and observed both genetic and non-genetic factors had no significant effect on service per conception. A number of other factors which might have influenced the variation in service per conception are the quality and quantity of semen used in artificial insemination, improper detection of heat, failure to inseminate at appropriate time and skill of the inseminator. The other related factors are the level of fertility which may be influenced the age of bulls and cows, season of the year, age of semen, diseases, semen handling techniques and other environmental factors.

\section{Gestation length}

The Least-Squares means of gestation length along with standard error for different genetic groups are presented in Table 1 and 2 . The highest gestation length is observed in $\mathrm{SL} \times \mathrm{L}(280.63 \pm 13.75$ days) for first lactation. The lowest gestation length was found in $\mathrm{J} \times \mathrm{F}$ (261.06 \pm 6.87 days) for first lactation and in $\mathrm{J} \times \mathrm{L}(274.60 \pm 11.39$ days) for second lactation. The gestation period was not significantly affected $(\mathrm{P}<0.05)$ by genetic groups. The results 
are in agreement with Majid et al. (1995), who reported a non-significant variation in gestation period among different genotypes. Similar results were also obtained by Sultana (1995) and Rahman et al. (1993). They found a range of gestation period of 270-285 days and no significant variations were observed in gestation length among different breeds and crossbreds. Nahar et al. (1992) also reported that the gestation period of different crosses varied little from 280 days.

\section{Post-partum heat period}

The Least-Squares means of postpartum heat period along with standard error for different genetic groups are presented in Table 1 and 2 . The highest PPH is observed in $\mathrm{J} \times \mathrm{L}(120.75 \pm 18.21$ days $)$ for first lactation. The analysis of variance showed that the genotype had a significant $(\mathrm{P}<0.01)$ effect on post-partum heat period. LSD test indicated no significant differences between the genotype $\mathrm{J} \times \mathrm{F}$ and $\mathrm{SL} \times \mathrm{L} ; \mathrm{J} \times \mathrm{L}$ (Table 1). The results of this study agree with the findings of Nahar et al. (1992). Majid et al. (1995) found that a little variation in PPE among different genetic but statistically non- significant. Nahar et al. (1989) reported that different breeds had a significant effect on PPH. They found that PPH in different breed groups ranged from $113.93 \pm 5.45$ to $150.71 \pm 4.42$ days. Post-partum heat period is a very important reproductive trait in dairy herd. Hafez (1993) suggested that the post-partum breeding should be delayed up to 60-90 days after parturition, when the uterus undergoes recovery and preparation for the next pregnancy.

\section{REFERENCES}

Ahmed, N. 1992. Problems and Prospects of Livestock in Bangladesh. in : Proc. Work on Livestock Development in Bangladesh. 16-18. July, 1991 pp. 8-14.

Alam, J., Akteruzzaman, M., Rahman, A. and Ahmed, Z. 2007. Comparative performance of Local x crossbred cows in Bangladesh. Ind. J. Dairy Sci., 47: 112-117.

Ansell, R. H. 1985. Cattle breeding in the tropics. World Anim. Rev., 54: 30-38.

BBS. 2010. Statistical Yearbook of Bangladesh, Bureau of Statistics, Ministry of Planning, Dhaka, Bangladesh.

Chaudhury, M. Z., Tahir, M. J. and Rafique, M. 1994. Production performance and milk production efficiency in different filial groups of $\mathrm{H}$ Friesian $\times$ Sahiwal half-breds. Asian Australasian J. Anim. Sci., 7: 383-387.

Deal, D. S., Aroraand, K. C. and Rath, S. S. 1991. Evaluation of performance traits in half bred cattle. Indian J. Dairy Sci., XLIV 171.

DLS. 2006. Annual report of Directorate of Livestock Services, Ministry of Livestock and Fisheries, Dhaka, Bangladesh.

FAD. 1997. Production Year Book, Rome, Italy. FAD.

Hafez, E. S. E. 1993. Reproduction in Farm Animals. $6^{\text {th }}$ edn. Lea and Febiger. USA.

Harvey, W. R. 1990. Mixed Model Least-Squares and Maximum Likelihood Computer Programme. PC-2 version. Mimeograph. Ohio State University, Ohio, USA. 
Hossain, M. A. and Routledge, S. F. 1982. Performance of crossbred and local cattle under village condition in Pabna district of Bangladesh. Proceeding of "Maximum livestock production from minimum land" Seminar, pp. 161-167.

Maarof, M. N., AI-Ant, L. M. and Raseed, S. T. 1987. Performance of Jersey cattle. Ind. J. Anim. Sci., 57: 719-727.

Majid, M. A., Nahar, T. N., Talukder, A. I. and Rahman, M. A. 1995. Factors affecting the reproductive efficiency of crossbred cows. Bangla. J. Livestock Res., 2: 18-22.

Nahar, N., Mostafa, K. G. and Amin, M. R. 1989. A comparative study on the performance of FI crossbred cows. Bangla. J. Anim. Sci., 18: 55-62.

Nahar, T. N., Islam, M. and Hasnath, M. A. 1992. A comparative study on the performance of crossbred cows under rural conditions. Asian Australasian J. Anim. Sci., 5: 435-438.

Rahman, M. F., Ahmed, N. and Ahmed, A. R. 1987. A comparative study on some productive and reproductive performance of dairy cows at Savar Dairy and Cattle Improvement Farm. Bangle. Vet. J., 21: 55-61.

Rahman, M. F., Islam, M. S., Hossain, M. A., Prodhan, M. A. M. and Rahman, A. 2009. Reproductive patterns of different breeds of cows in Bangladesh. Bangla. J. Livestock Res., 1: 19-24.

Snedecor, G. W. and Cochran, W. G. 1980. Statistical methods, $7^{\text {th }}$ edn. The Iowa State University Press. Iowa, USA.

Sultana, R. 1995. Quantitative analysis of reproductive performance of purebred and their crosses in the Savar Dairy Farm. M. Sc. Thesis. Dept. of Animal Breeding and Genetics. BAU, Mymensingh. 